\title{
Dari Jalan Kerajaan Menjadi Jalan Pertokoan Kolonial: Malioboro 1756-1941
}

\section{SITI MAHMUDAH NUR FAUZIAH}

Alumnus Program Studi S1 Departmen Sejarah FIB UGM

Email: smnurfauziah@gmail.com

\begin{abstract}
In the colonial period, the beginning of the 20th century became the starting point of the emergence of modern shopping streets in almost all cities in Java, such as Groote Postweg (Postal Highway, now Jalan Ahmad Yani) in Semarang, Bragaweg (Jalan Braga) in Bandung, Jalan Pasar Baru in Weltevreden, Jalan Tunjungan in Surabaya, and Kayutangan (now Jalan Basuki Rahmat) in Malang. In Yogyakarta, Malioboro became the most modern and crowded colonial shopping street at that time.

Since the establishment of the Sultanate of Ngayogyakarta Hadiningrat in 1756 Malioboro has played an important role in the palace's urban planning as a rajamarga (royal road) for certain ceremonies and has become an integral part of the concept of the palace philosophy line which is full of meaning. This paper will describe the development of Malioboro from a royal road into a colonial shopping street in 1756-1941 more comprehensively.

The method used in this research is a historical method which includes the selection of topics, collecting resources, verification, interpretation, and writing. As the cornerstone of this research, the data used is relevant data from Gegevens over Djokjakarta's archives, newspapers, magazines, Rijksblad van Sultanaat Djogjakarta, Kleian's Adresboek van Geheel Nederlandsch-Indie, Telefoongids voor Java, Madoera en Bali, memoirs, interviews, maps and pictures related to Malioboro.
\end{abstract}

\footnotetext{
Abstrak

Pada masa kolonial, permulaan abad ke-20 mejadi titik awal dari munculnya jalanjalan pertokoan modern di hampir seluruh kota di Jawa, seperti Groote Postweg (Jalan Raya Pos, sekarang Jalan Ahmad Yani) di Semarang, Bragaweg (Jalan Braga) di Bandung, Jalan Pasar Baru di Weltevreden, Jalan Tunjungan di Surabaya, dan Kayutangan (sekarang Jalan Basuki Rahmat) di Malang. Di Yogyakarta, Malioboro menjadi jalan pertokoan kolonial paling modern dan paling ramai saat itu.

Sejak berdirinya Kasultanan Ngayogyakarta Hadiningrat pada 1756 Malioboro telah memainkan peran yang penting dalam tata kota kraton sebagai rajamarga (jalan kerajaan) untuk seremonial tertentu dan menjadi bagian integral dalam konsep garis filosofi kraton yang sarat makna. Tulisan ini akan menguraikan perkembangan Malioboro tahun 1756-1941 dari sebuah jalan kerajaan hingga menjadi jalan pertokoan kolonial secara lebih komprehensif.
}

Keywords: Malioboro; colonial shopping street

Kata kunci: Malioboro; jalan pertokoan kolonial 
Metode yang digunakan dalam penelitian ini adalah metode sejarah yang meliputi pemilihan topik, pengumpulan sumber, verifikasi, interpretasi, serta penulisan. Sebagai landasan dalam penelitian ini, data yang digunakan adalah data yang relevan dari arsip Gegevens over Djokjakarta, surat-surat kabar dan majalah, Bijblad op het Staatsblad van Nederlandsch-Indie, Rijksblad van Sultanaat Djogjakarta, Kleian's Adresboek van Geheel Nederlandsch-Indie, Telefoongids voor Java, Madoera en Bali, memoar, wawancara, peta dan foto terkait Malioboro.

\section{Pengantar}

Semenjak awal abad ke-20 muncul jalan-jalan pertokoan modern di kotakota di Hindia Belanda. Menurut Raap (2015: 319), konsep dengan jalanan pertokoan ala Eropa, dengan deretan toko di kedua sisi jalan, tampaknya menjadi tren di Hindia Belanda. Jalan pertokoan tersebut tumbuh di sekitar pecinan, jalan utama kota, atau jalan arteri perifer kota lama.

Di Yogyakarta, jalan pertokoan kolonial yang paling tersohor kala itu adalah Malioboro. Secara spasial, berdasarkan sejumlah artikel surat kabar dan juga tulisan lain yang terbit pada masa kolonial, Malioboro seringkali merujuk pada jalanan sepanjang \pm 2 kilometer dari utara kraton (setelah Alun-Alun Lor) ke utara sampai Tugu yang terdiri dari beberapa ruas jalan: Kadasterstraat (Pangurakan); Residentielaan dan Patjinan (Margo Mulyo); Malioboro; dan Toegoeweg atau Toegoe Kidul (Margo Utomo). ${ }^{1}$ Kadasterstraat membentang dari utara Alun-Alun Utara hingga Titik Nol Kilometer; Residentielaan dari Titik Nol Kilometer hingga Benteng Vredeburg; Patjinan dari Pasar Gedhe hingga Ketandan; Malioboro dari Kepatihan hingga teteg sepur; dan Toegoeweg dari teteg sepur hingga Tugu.

\section{Toponimi Malioboro}

Ada berbagai pendapat tentang asal muasal kata 'Malioboro'. Nama Malioboro menurut catatan dari pihak kapujanggan kraton diambil dari nama salah

1) Zaman dulu banyak jalan yang mengikuti nama wilayah di sekitarnya. Misalnya, "Patjinan" di utara Residentielaan disebut "Patjinan" tanpa tambahan "weg" atau "jalan" karena terdapat pemukiman orang-orang Cina/Tionghoa di dekatnya. Pada masa Hindia Belanda nama-nama jalan umumnya menggambarkan keadaan di sekelilingnya; sifat jalannya, seperti Hoofdstraat (jalan utama yang berbatu), Tamarindelaan (jalan dengan pohon-pohon asam di tepinya), dsb.; dan tujuan jalannya, contohnya Stationsweg (Jalan Stasiun) karena menuju ke stasiun dan Passerweg (Jalan Pasar) karena menuju ke pasar. Dalam bahasa Belanda terdapat beragam istilah untuk jalan, yaitu "weg" (jalan utama atau jalan arteri/protokol), "straat" (jalan yang berbatu-batu), "laan" (jalan dengan pepohonan di tepinya), dan "boulevard" (adimarga atau yang meminjam istilah bahasa Perancis artinya jalan raya bergengsi, lebar, dan panjang). Nama jalan kadang juga diberikan untuk menghormati tokoh-tokoh atau tema-tema tertentu. Lebih lanjut lihat Raap, Olivier Johannes, Kota di Djawa Tempo Doeloe (Jakarta: Kepustakaan Populer Gramedia, 2015), hlm. 167-200. Toegoeweg juga sering disebut oleh masyarakat setempat dengan Toegoe Kidoel karena letaknya yang ada di sebelah selatan Tugu. Sedangkan ruas jalan di sisi utara, timur, dan barat dinamai sesuai dengan posisinya terhadap Tugu, yaitu Toegoe Lor, Toegoe Wetan, dan Toegoe Koelon. 
satu pesanggrahan Jayengrana (Darmosugito, 1956: 26) dalam roman JawaIslam populer. Sementara itu, dahulu sebagian orang berpendapat Malioboro berasal dari kata Marlborough-gelar Jenderal John Churchill (1650-1722) dari Inggris yang pengucapannya sekilas memang terdengar hampir samayang disanggah oleh Dr. O.W. Tichelaar melalui tulisannya "The Derivation (from Sanskrit) of the Streetname Malioboro in Yogyakarta. Tichelaar (1971: 185190 dalam Carey, 1984: 53) yang berargumen bahwa Malioboro menjadi jalan yang terlalu penting bagi orang Jawa untuk diberi nama orang Inggris yang merupakan orang asing bagi mereka. ${ }^{2}$ Sebagaimana yang telah diungkapkan Profesor C. C. Berg di dalam kuliahnya di Leiden University pada 1950an dan 1960-an, menurut Tichelaar (1971: 187-188 dalam Carey, 1984: 53) asal-muasal kata Malioboro dapat dirunut dari bahasa Sansekerta, yaitu 'malyhabara' yang artinya 'dihiasi dengan untaian bunga'. Menurut Carey, besar kemungkinan jalan ini sejak awal telah dikenal sebagai "Jalan Malioboro" meskipun masih disangsikan asal muasal nama Malioboro ini hingga kata "maliabara' benar-benar ditemukan dalam naskah yang berasal dari Yogyakarta pada pertengahan abad ke-18 (Carey, 1984: 51-52). Sementara itu, dalam konsep garis filosofi Kraton Yogyakarta yang membentang dari Panggung Krapyak hingga Tugu nama "Malioboro" dapat dimaknai dari kata malia yang berarti jadilah wali dan bara yang berasal dari kata ngumbara atau mengembara (Umar Priyono, dkk., 2015: 82).

\section{Malioboro dalam Tata Kota Kasultanan Ngayogyakarta Hadiningrat}

Pasca Perjanjian Giyanti pada 13 Februari 1755, Pangeran Mangkubumi atau yang kemudian bergelar Sri Sultan Hamengku Buwono Senopati Ing Ngalaga Ngabdurrahman Sayidin Panatagama Kalifatullah Ingkang Jumeneng Kaping I mendirikan Kraton Ngayogyakarta Hadiningrat di sekitar Ayogya/Ayodhya tepatnya di Hutan Paberingan, Dukuh Pacethokan, di sebuah distrik bernama Mataram yang sebelumnya merupakan bagian dari Kerajaan Mataram Islam. Istana selesai dibangun pada tanggal 13 Sura 1682 tahun Jawa atau 7 Oktober 1756 dan ditandai dengan candrasengkala memet berbentuk dua ekor naga yang menghadap berlawanan dan ekornya saling berbelitan di tengah, yang dibaca 'dwi naga rasa tunggal', artinya 1682 Tahun Jawa atau 1756 Masehi.

Malioboro sendiri sudah ada bersamaan dengan berdirinya Kraton Yogyakarta (Kabare, Edisi 156 Tahun XIII, Juni 2015: 9). Hal ini hampir sejalan dengan pendapat Peter Carey (1984: 52) yang mengatakan bahwa jalan raya ini telah dibangun dan digunakan untuk tujuan seremonial tertentu selama lima puluh tahun sebelum orang Inggris mendirikan pemerintahannya di Jawa

2) Dalam hal ini, Tichelaar mengaitkan Jalan Malioboro dengan letaknya yang terbentang dari kompleks Kraton Yogyakarta hampir tepat ke utara ke arah Gunung Merapi yang memiliki arti penting bagi kraton. 
(1811-1816). Jika ditelusuri lebih lanjut dalam beberapa sumber mengenai lokasi yang menjadi cikal-bakal kraton Yogyakarta, kemungkinan jalan yang sekarang menghubungkan Tugu dengan Kraton Yogyakarta tersebut telah ada sebelumnya sebagai jalan penghubung menuju Pesanggrahan Gerjitawati atau Ayogya/Ayodhya ${ }^{3}$-suatu tempat yang diperkirakan berada di lokasi yang kini dijadikan istana Kasultanan Ngayogyakarta Hadiningrat oleh Pangeran Mangkubumi-dan jalan tersebut sering dilalui oleh rombongan Kerajaan Mataram Islam dari Kartasura yang membawa jenazah raja atau keluarga kerajaan yang akan disemayamkan di Imogiri dengan singgah terlebih dahulu di Pesanggrahan Gerjitawati sebelum meneruskan perjalanan ke Imogiri.

Malioboro sebagai penghubung antara tugu dan kraton tidak dapat dilepaskan dari konsep filosofi tata kota Kraton Yogyakarta. Secara simbolis filosofis, garis filosofi dengan simpul-simpulnya berupa Panggung KrapyakKraton Yogyakarta-Tugu Golong Gilig melambangkan konsep 'sangkan paraning dumadi' atau 'asal dan tujuan dari adanya hidup' (wawancara dengan K.R.T. Jatiningrat, 10 Mei 2016). Dari Panggung Krapyak menuju Kraton Yogyakarta menggambarkan perjalanan manusia sejak di dalam kandungan, lahir, beranjak dewasa, menikah hingga memiliki anak (sangkaning dumadi) (Umar Priyono, dkk., 2015: 61-76). Sedangkan dari Tugu Golong Gilig ke arah selatan menggambarkan perjalanan manusia ketika hendak menghadap Sang Khalik (paraning dumadi), meninggalkan alam fana (dunia) menuju alam baka (akhirat) (Umar Priyono, dkk., 2015: 77-102).

Sebagai rajamarga atau jalan kerajaan, Malioboro berfungsi sebagai jalan raya seremonial yang sesuai dengan tradisi India, terutama pada hari perayaan, dihiasi dengan untaian bunga (malyabhara) (Carey, 1984: 51). Jalan yang membentang lurus dari utara ke selatan ini menjadi saksi bisu prosesi kedatangan para gubernur jenderal dan pejabat Eropa lainnya baik sipil maupun militer serta tamu kerajaan lain dari arah utara menuju kraton saat kunjungannya di Yogyakarta yang disambut oleh sultan dan para prajurit kraton bersenjata. Menurut Carey (1984:58), seremonial masuknya gubernur jenderal melewati Jalan Malioboro memenuhi dua tujuan penting bagi orang Jawa, yaitu untuk memberikan penghormatan yang layak diterima oleh tamu terhormat dan untuk "menjinakkan" kekuasaannya yang besar.

\section{Malioboro: Dari Jalan Kerajaan menjadi Jalan Pertokoan Kolonial}

Sebagaimana yang telah diuraikan di atas, sejak awal keberadaan Kasultanan Ngayogyakarta Hadiningrat secara spasial Malioboro telah menjadi bagian yang integral dari tata ruang ibukota kerajaan. Disamping sebagai rajamarga

3) Gerjitawati merupakan dalem atau kediaman milik Kerajaan Mataram yang dibangun oleh Sunan Amangkurat. Dalem ini kemudian diubah namanya menjadi Ayogya/ Ayodhya oleh Sunan Paku Buwono II. 
dan terletak pada garis filosofi kraton yang sangat sarat makna, disini terdapat Kepatihan sebagai pusat pemerintahan sehari-hari dan Pasar Gedhe sebagai pusat perekonomian warga. Keduanya merupakan bagian dari kesatuan tata ruang yang disebut catur gatra tunggal atau catur sagotra. Dalam konsepsi ini terdapat empat elemen penting, yaitu politik (Kraton dan Kepatihan), keagamaan (Masjid Gedhe), ekonomi (Pasar Gedhe), dan sosial (Alun-Alun).

Kepatihan dibangun oleh Sri Sultan Hamengku Buwono I dengan gaya arsitektur tradisional berupa joglo dan limasan di sisi timur ruas Malioboro. Kompleks ini digunakan sebagai kantor dan kediaman pepatih dalem (rijkbestuurder) yang diangkat oleh sultan atas persetujuan pemerintah kolonial. Sesuai dengan isi Perjanjian Giyanti, pemerintahan di Kasultanan Ngayogyakarta Hadiningrat dilaksanakan dengan sistem praja kejawen dimana sultan dibantu oleh pepatih dalem dalam menjalankan pemerintahan seharihari. Tercatat ada delapan orang pepatih dalem yang pernah menempati kompleks ini mulai dari Kanjeng Raden Adipati Danureja I hingga Kanjeng Pangeran Harya Adipati Danureja VIII.

Pasar Gedhe yang berjarak sekitar 450 meter ke selatan dari Kompleks Kepatihan awalnya hanya berupa tanah lapang. Tempat ini secara resmi dipergunakan sebagai ajang pertemuan rakyat setelah ditunjuk oleh Sri Sultan Hamengku Buwana I tahun 1758 dan selanjutnya orang-orang mulai memanfaatkan dengan mendirikan payon-payon untuk melakukan transaksi jual beli sebagai peneduh panas dan hujan (V. Wiratna Sujarweni, 2012: 75). Semakin lama semakin banyak pedagang, terutama Pribumi, yang berjualan disini sehingga dibangunlah los-los berbentuk limasan dengan tiang kayu jati tanpa dinding yang berjajar dari selatan ke utara untuk para pedagang pada 1830. Los-los berupa kayu tersebut kemudian diganti dengan bangunan beton yang lebih kokoh oleh Hollandsche Beton Maatschappij atas perintah Sri Sultan Hamengku Buwono VIII tahun 1923-1926 dan dijuluki sebagai "Een der Mooiste Passers op Java" atau "Pasar Terindah di Jawa". Pasar juga dilengkapi dengan bangunan kantor dinas pasar di sisi selatan. Setelah Sri Sultan Hamengku Buwono IX naik tahta dan mentitahkan nama-nama Jawa bagi semua instansinya di bawah pemerintahan Kasultanan Yogyakarta, nama pasar itu dinamakan Pasar Beringharjo (Arwan Tuti Artha, 2000: 32).

4) Beringharjo berasal dari kata 'bering' dan 'harjo'. 'Bering' dari nama Hutan Paberingan karena lokasi pasar ini dulunya adalah sebuah hutan bernama Paberingan dan 'harjo' dari kata raharjo yang artinya baik dan sejahtera dengan harapan tempat ini menjadi baik dan membuat rakyat sejahtera. Ada pula yang mengartikan nama Beringharjo dari kata 'jember' yang artinya basah atau lembab karena keadaan pasar sebelumnya yang berupa daerah rawa-rawa dan lembab, 'ring' yang artinya kering, dan 'harjo' yang artinya indah dan bersih sehingga beringharjo berarti daerah yang semula basah dan lembab kemudian kering dan menjadi indah dan bersih. Pada masa-masa awal berdirinya Kasultanan Ngayogyakarta Hadiningrat dikenal ada dua Pasar Gedhe, yaitu Pasar Gedhe di daerah Kotagedhe dan Pasar Gedhe di utara Benteng Vredeburg yang disebut juga oleh masyarakat sekitar dengan nama Pasar Loring Loji karena letaknya yang persis di utara bangunan loji Belanda, yakni Loji 

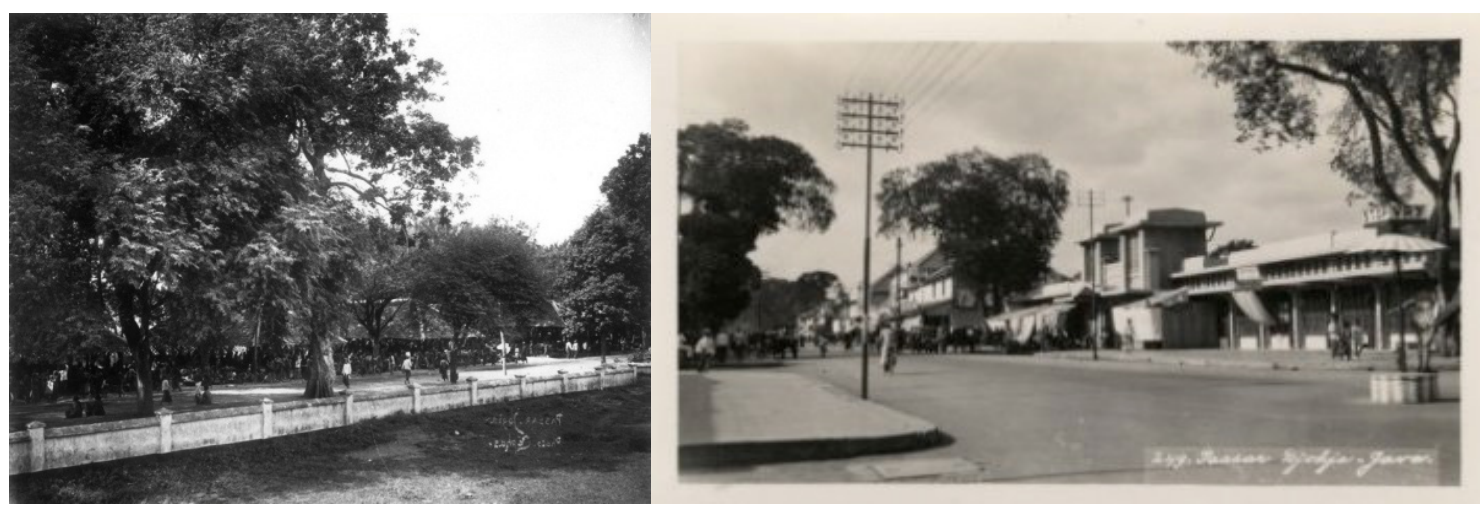

Figur 1. Pasar Gedhe sebelum dan sesudah direnovasi oleh Hollandsche Beton Maatschappij. Foto sebelah kiri diambil sekitar tahun 1900 dari arah utara Benteng Vredeburg memperlihatkan sisi selatan pasar dengan los-los kayu yang memanjang, sedangkan foto sebelah kanan diambil sekitar tahun 1935 dari sisi barat ruas jalan Patjinan memperlihatkan bagian depan pasar yang modern. Sumber: kitlv.nl

Tiap harinya pasar selalu ramai oleh para pedagang dan pembeli baik dalam maupun luar Kota Yogyakarta.

Sebelum munculnya toko-toko modern di Malioboro, selama kurun waktu 1756-1830 selain Kompleks Kepatihan dan Pasar Gedhe dibangun pula penjara di selatan Alun-Alun Utara; beberapa fasilitas kolonial seperti benteng, kediaman residen, dan kantor residen di ruas Residentielaan, serta pemakaman Eropa di timur Pasar Gedhe; dan sositet di Kawasan Malioboro yang seluruhnya dapat dilihat pada Plattegrond van de Hoofdplaats Jogjakarta Omstreeks koleksi KITLV. Dalam The Guide Book of Benteng Vredeburg Museum (M. Rosyid Ridlo, 2013: 3-5) disebutkan bahwa benteng tersebut awalnya dibangun tahun 1756 oleh Sultan Hamengku Buwono I atas kesepakatan sultan dengan VOC yang diwakili oleh Residen Yogyakarta yang pertama, Cornelis Donkel (1755-1761), dengan konstruksi sederhana dari tanah yang diperkuat dengan pohon-pohon kelapa dan palem serta beberapa bangunan di dalam benteng yang dibuat dari bambu. Pada 1767-1787 benteng direnovasi menjadi bangunan yang lebih permanen atas usul Gubernur Pesisir Utara Jawa di Semarang, W.H. Ossenberch, dan di bawah pengawasan arsitek Belanda, Ir. Frans Haak. Benteng yang ada di sisi timur ruas Residentielaan atau selatan Pasar Gedhe ini dinamakan Benteng Rustenburg yang artinya benteng peristirahatan dan oleh masyarakat setempat sering disebut dengan Loji Besar karena ukuran bangunannya yang besar dibandingkan dengan bangunan-bangunan Belanda lain di sekitarnya. Di dalam benteng terdapat tempat tinggal tentara, gudang-gudang, penjara, gereja, dan bangunanbangunan administratif lainnya. Pada awal abad ke-19 di timur benteng terbentuk pemukiman Belanda pertama (Loji Kecil). Setelah pemugaran bangunan akibat gempa bumi tahun 1867 nama benteng diubah dari Rustenburg menjadi Vredeburg, yang artinya benteng perdamaian.

Besar (Benteng Vredeburg). 


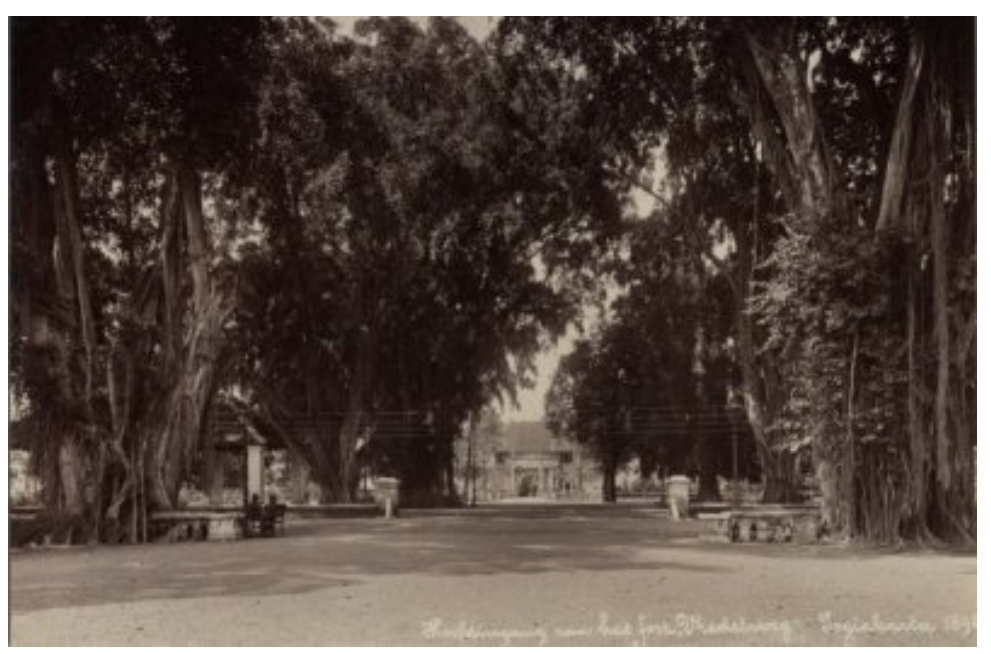

Figur 2. Benteng Vredeburg tahun 1896. Foto diambil dari halaman Kediaman Residen ke arah timur. Sumber: kitlv.nl

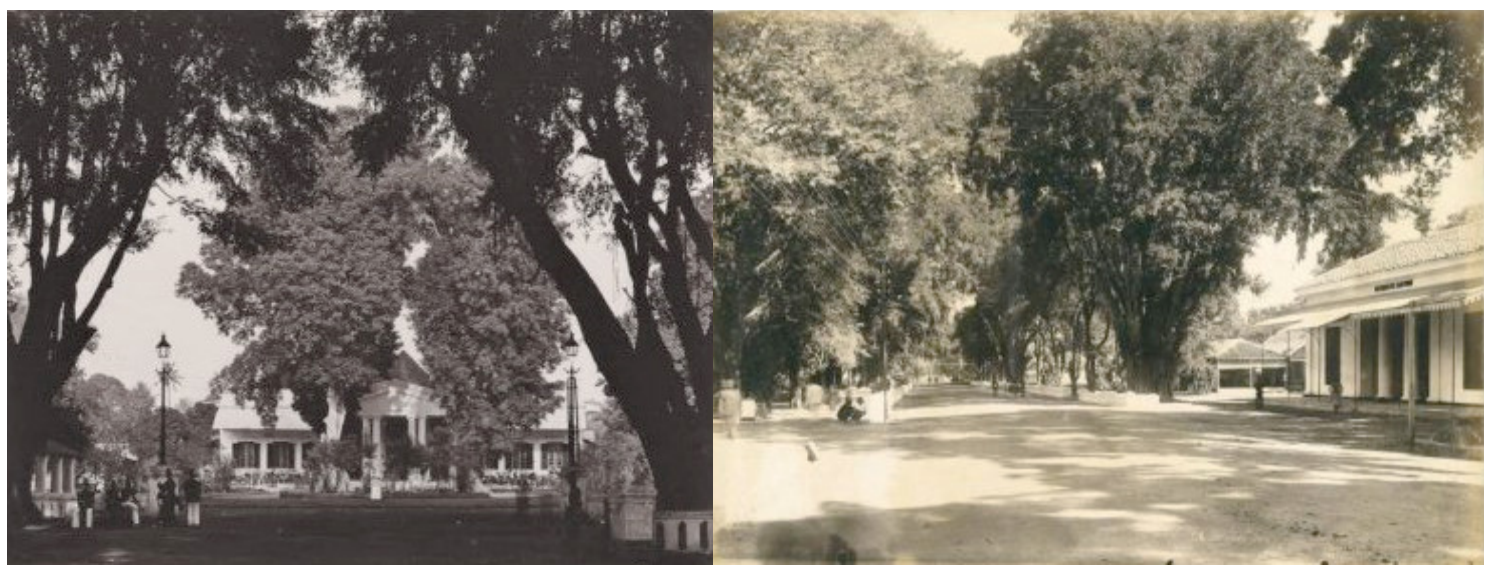

Figur 3. Kediaman Residen Yogyakarta sebelum tahun 1874 (kiri) dan pemandangan jalan di Yogyakarta dengan kantor residen di sisi kanan tahun 1896 (kanan). Sumber: kitlv.nl.

Kediaman residen (sekarang Gedung Agung) dan kantor residen (di lokasi yang sama sekarang ditempati oleh Mirota Batik) dibangun di seberang benteng. Kediaman Residen disebut juga dengan Loge Tuin atau Loji Kebon karena halaman tamannya yang luas ditumbuhi banyak tanaman. Tempat inilah yang disebut sebagai rumah dinas resmi residen oleh Kapten William Robison dalam suratnya kepada Lord Minto-Gubernur Jenderal Inggris di India-ketika menceritakan kunjungannya di Kota Yogyakarta tahun 1811. ${ }^{5}$ Tahun 1824 atas inisiatif Residen Antonie Hendrik Smissaert, dilakukan perbaikan dan pembangunan kembali Kediaman Residen dengan A. Payen sebagai arsiteknya. Bangunan dipugar kembali tahun 1869 pasca gempa bumi besar yang melanda Yogyakarta tahun 1867. Disini kerap diselenggarakan jamuan makan malam dalam rangka perayaan ulang tahun dan peringatan hari penobatan Ratu Belanda yang dihadiri oleh seluruh pejabat tinggi dari berbagai etnis dan golongan di Yogyakarta.

5) Ia tiba di Yogyakarta tanggal 24 September 1811 malam hari setelah kunjungannya di Kasunanan Surakarta dalam rangkaian ekspedisinya di Pulau Jawa. Tim Hannigan, Raffles dan Invasi Inggris ke Jawa (Jakarta: Kepustakaan Populer Gramedia, 2015), hlm 121. 


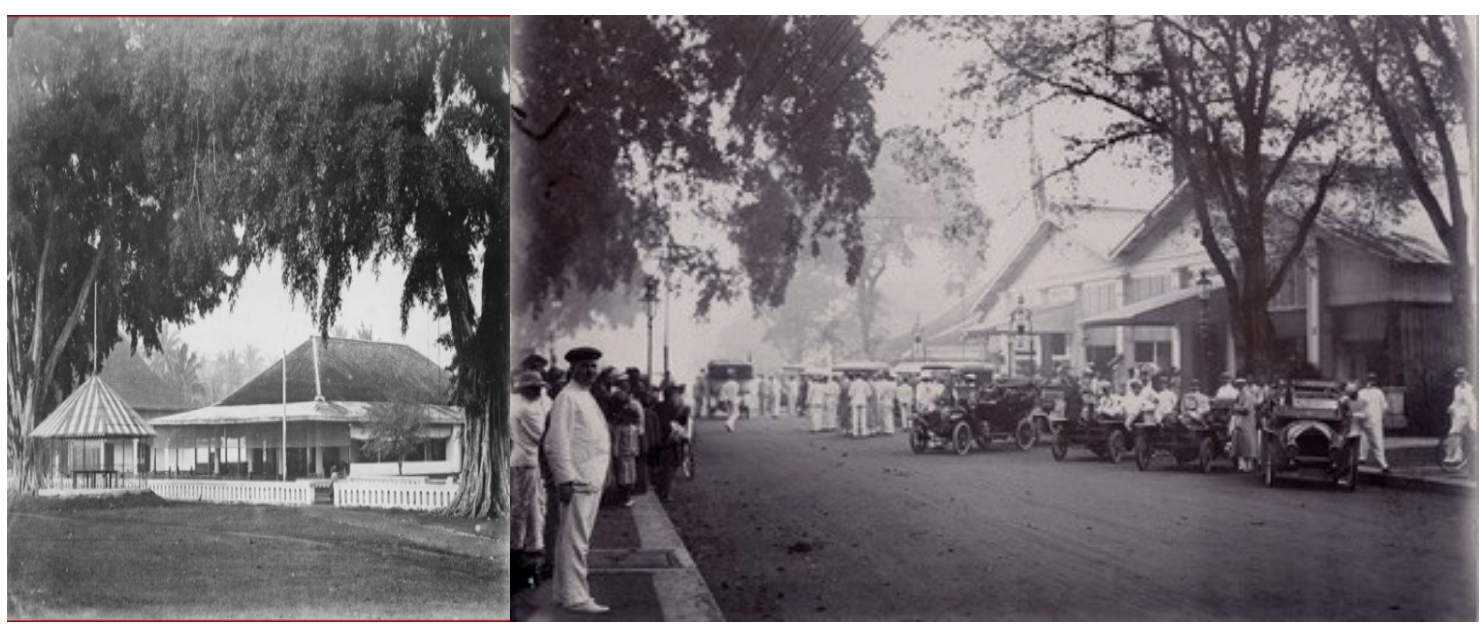

Figur 4. Societeit de Vereeniging sekitar tahun 1860-1880 (kiri) dan Societeit de Veereniging tahun 1909 (kanan). Pada foto sebelah kanan terlihat kendaraan-kendaraan dari para peserta perlombaan mobil yang diselenggarakan oleh De Semarangsche Auto Club tanggal 25-26 Desember 1909. Sumber: tropenmuseum.nl (kiri) dan kitlv.nl (kanan).

Berdekatan dengan Kediaman Residen, bangunan sositet di sudut ruas Residentielan mulanya merupakan 'geneverhuis' (rumah tempat minuman keras) atau 'rumah bicara' untuk tempat minum (minuman keras) dan tempat berbincang-bincang bagi orang-orang Eropa yang dibangun tahun 1818. Tanggal 4 Juni 1822 gedung tersebut menjadi milik satu perkumpulan orang-orang Eropa yang bernama "de Vereeniging" sehingga sejak itu gedung pertemuan tersebut terkenal dengan nama "Societeit de Vereeniging" (Tashadi, 2005: 51). Dalam perkembangannya, Societeit de Vereeniging atau yang oleh orang-orang Pribumi sering disebut dengan Kamar Bola ini lebih diperuntukkan bagi orang-orang sipil Eropa, sedangkan untuk mereka yang bekerja di militer terdapat tempat khusus yaitu di Societeit Militair (1830) yang terletak di bagian belakang Benteng Vredeburg.

Setiap malam Minggu, khususnya malam tahun baru, Societeit de Vereeniging banyak dikunjungi oleh para pengusaha perkebunan Eropa dan keluarganya yang tinggal di sekitar kota yang datang berbondong-bondong mengendarai kereta (Tashadi, 2005: 52). Residen dan para pejabat Eropa lainnya juga sering datang ke tempat ini. Di luar lingkaran orang-orang Eropa, hanya para elit dari golongan Pribumi dan Timur Asing atau orang yang mampu secara finansial yang diperbolehkan masuk. Disini mereka bisa makan dan minum di restoran dan bar yang disediakan, bermain bola bilyard dan bowling, berjudi lewat permainan roulette dan baccarat ala kasino, berdansa, menikmati pertunjukkan musik dan orkestra, serta menonton teater atau opera ala Belanda. Beberapa aktor dan penyanyi dari luar negeri datang untuk menggelar pertunjukkan teater dan konser disini, seperti Anton Verheyen, Adavan Duyl, Henri Brondgeest, Warrens Bedrijf, Caroline van Dommelen, Martha Walden, Poldi Rei dan Louis Dornay. Pada siang hari gedung Societeit de Vereeniging biasanya dimanfaatkan untuk anak-anak sekolah-baik sekolah 
Belanda maupun sekolah-sekolah yang mengajarkan bahasa Belanda-dan pada musim pacuan kuda dipakai sebagai pusat kegiatan bagi para pencinta pacuan kuda dengan nama Wedloop Societeit Mataram (WSM) (Tashadi, 2005: $53)$.

Tak jauh dari Societeit de Vereeniging, orang-orang Tionghoa yang telah lama menetap di Yogyakarta membangun Chinese Societeit Hwa Kiauw di ruas Kadasterstraat No. 4 (sekarang digunakan sebagai gedung Perpustakaan Museum Sonobudoyo) pada 1775. Di Chinese Societeit Hwa Kiauw atau yang di dalam buku-buku telepon terbitan masa kolonial sering disebut dengan Societeit Mataram Hwa Kiauw ini orang-orang Tionghoa biasa berkumpul, bercengkerama, serta menikmati berbagai macam hiburan dan kesenian. Di tahun 1931 pihak Hwa Kiauw memperluas bangunan sositet dengan membeli sebuah rumah di ruas Kadasterstraat milik seorang tuan tanah bernama R. M. E. Raaff yang kemudian direnovasi dengan ditambah beberapa ornamen baru. Selain itu, mereka juga telah membeli rumah lain yang lebih kecil ukurannya di Societeitstraat yang setelah diperbaiki dijadikan klinik rawat jalan gratis untuk orang-orang yang membutuhkan dari segala lapisan masyarakat.

Selama periode cultuurstelsel (1830-1870) para pemodal swasta mulai menyewa tanah kasultanan dan membuka berbagai usaha industri dan perkebunan di Yogyakarta. Sejak saat itu semakin banyak pengusaha swasta, terutama Eropa, yang datang. Guna mengakomodir jemaat Eropa beragama Protestan yang kian bertambah maka dibangunlah Protestansche Kerk (sekarang GPIB Margo Mulyo) di selatan Kantor Residen untuk menggantikan gereja di dalam Benteng Vredeburg. Gereja yang dibangun selama 15 Oktober 185313 Oktober 1957 dan didesain oleh Ir. P.A. Holm ini diresmikan tanggal 15 Oktober 1857.

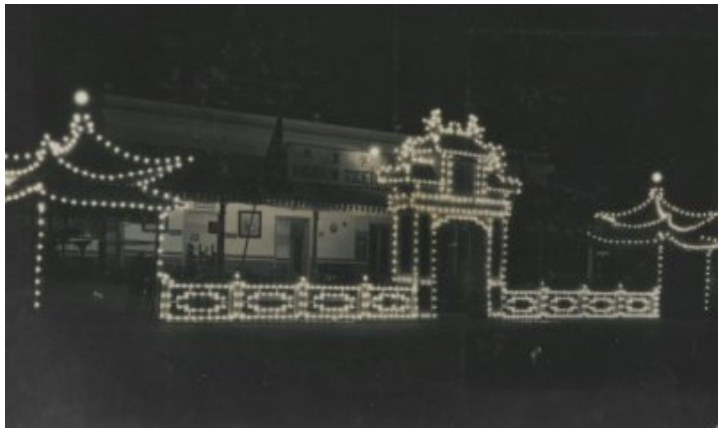

Figur 5. Chineesche Societeit Hwa Kiauw dihiasi lampulampu saat perayaan 50 tahun Ratu Wilhelmina, tahun 1930. Pada akhir tahun 1945, bangunan ini lebih dikenal dengan nama Chung Hua Tsung Hui (CHTH) sesuai dengan nama perkumpulan Tionghoa yang ada disana. Sumber: kitlv.nl

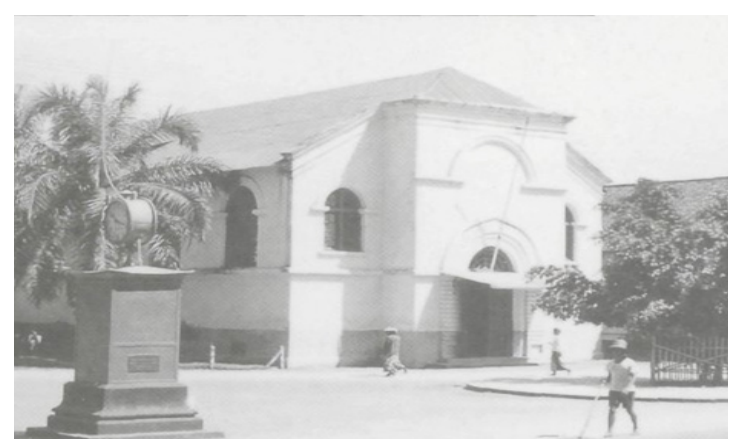

Figur 6. Protestansche Kerk di sudut ruas Kantoorlaan dan Residentielaan. Di sisi kiri foto tampak sebuah jam kota persembahan masyarakat Belanda kepada pemerintahnya untuk memperingati satu abad kembalinya Pemerintahan Kolonial Belanda dari Pemerintahan Inggris tahun 1916. Wilayah di sekitar jam kemudian dikenal dengan nama Ngejaman. Foto: G.H. van de Peppelvon Liebenstein. Sumber: Bruggen, van M.P., Wassing, R.S., dkk., Djokja en Solo Beeld van de Vorstensteden (Purmerend: Asia Maior, 1998), hlm. 127. 
Tahun 1870 F.W. Wieseman dan beberapa orang Eropa lainnya mendirikan Loji Mason (dalam bahasa Belanda disebut Huis van Overdenking yang artinya Rumah Pewangsitan) di ruas jalan Malioboro No. 16 (sekarang DPRD DIY). Loji ini dinamakan Loji Mataram atau sering dijuluki oleh masyarakat sekitar sebagai Loji Setan karena berbagai misteri yang menyelimutinya. Anggotanya terdiri dari berbagai macam etnis dan golongan. Dalam perkembangannya, para anggota mason ini memberikan sumbangsih yang cukup besar dalam hal pendidikan bagi orang-orang Bumiputera. Beberapa sekolah Frobel (Taman Kanak-Kanak) dan sekolah netral mereka dirikan di Yogyakarta, diantaranya adalah sekolah Frobel di Loji Mataram dan dua sekolah Hollandsch-Javaansche School (satu untuk laki-laki dan satu untuk wanita) di Danurejan atau Kepatihan yang setidaknya telah ada pada dekade kedua abad ke-20.

Bersamaan dengan dihapuskannya cultuurstelsel pada tahun 1870, status hukum swapraja menjadi hampir sama dengan daerah-daerah lain di Hindia Belanda yang berimplikasi pada hilangnya sejumlah hak-hak istimewa Yogyakarta. Namun demikian, dalam hal ekonomi Yogyakarta menjadi kian terbuka bagi perusahaan swasta dengan adanya UU Agraria tahun 1870. Beberapa tahun pasca diundangkannya UU Desentralisasi (Decentralisatie Wet) tahun 1903 menjadi titik puncak dari perencanaan kota-kota di Hindia Belanda, termasuk Yogyakarta. Malioboro yang berada di jantung kota menjadi kawasan yang mengalami perkembangan paling signifikan. Selama kurun 1870-1920-an sejumlah fasilitas didirikan di kawasan ini guna menunjang perekonomian Yogyakarta, diantaranya Stasiun Yogyakarta atau Stasiun Tugu (1887) oleh Staats Spoorwegen (SS) dengan jalur rel kereta api yang membentang dari barat ke timur melintasi Kawasan Malioboro; bank-bank seperti De Javasche Bank Kantor Cabang Yogyakarta (sekarang Bank Indonesia) tahun 1879 yang diarsiteki oleh Hulswitt dan Cuypers, Jasper Bank, dan Centrale Pensioenbank (C.P.B.) di Malioboro No. 8; Post, Telegraaf-, en Telefoonkantoor (PTT) tahun 1910-1912 (sekarang Kantor Pos Besar Yogyakarta) oleh Burgerlijke Openbare Werken (BOW); Kantor Asisten Residen (sekarang menjadi markas Korem 072 Pamungkas) tahun 1903 dan Kediaman Asisten Residen (1912); Pegadaian Ngupasan (1913); gedung perkantoran NILLMij (sekarang menjadi gedung Bank BNI '46) pada 1922-1924 yang juga ditempati oleh N.I. Escompto, Vorstenlandsche Radio Vereeniging, dan perusahaan lain; dan sekolah-sekolah yang pertumbuhannya semakin pesat terutama sejak 1908 sejalan dengan kebutuhan terhadap tenaga-tenaga terdidik.

Jalanan yang awalnya masih relatif sepi dengan pepohonan tumbuh di kanan kirinya ini mulai mengukukuhkan dirinya sebagai pusat ekonomi Yogyakarta. Pasar Gedhe kian ramai dan menarik para pengusaha dan pedagang, terutama orang-orang Tionghoa, untuk membuka warung di 


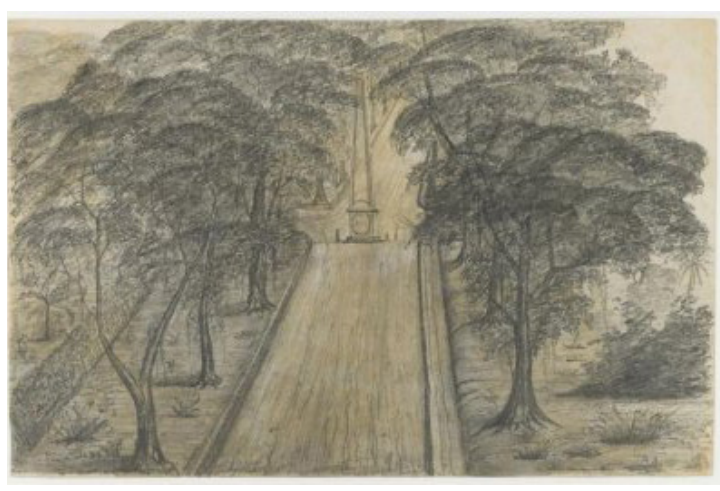

Figur 7. Sketsa karya Anton Baron Sloet van Oldruitenborgh tahun 1848. Dalam sketsa terlihat kedua sisi jalan masih ditumbuhi pepohonan besar dan belum terlihat adanya bangunan di sekitar Tugu Golong Gilig. Sumber: kitlv.nl. dekat pasar. Warung-warung juga mulai tumbuh di sekitar Tugu hingga Pasar Gedhe semenjak meluasnya penduduk Tionghoa dari Kranggan hingga ke sebelah selatan rel kereta api di wilayah Kota Yogyakarta atas izin sultan (Darmosugito, 1956: 26). Sebelum tahun 1880, pasar orang-orang Tionghoa tersebut tidak terlalu besar dan hanya terdiri atas warung-warung-warung yang termasuk besar ialah yang dekat dengan Kepatihan di sebelah utara benteng kompeni (Catatan R.M. Purwalelana dalam Abdurrachman Surjomihardjo, 2008: 55).

Pada awal abad ke-20 julukan kota 'transit' mulai melekat di kota ini karena letaknya yang strategis di tengah-tengah jalur kereta api Pulau Jawa. Sebagaimana yang diungkapkan oleh Darmosugito (1956: 25), Yogyakarta merupakan pintu dari 3 jurusan yang menghubungkan kota-kota bandar besar di Jawa (Semarang, Surabaya, dan Jakarta) dan menjadi satu-satunya jembatan penghubung antara Jawa Timur dan Jawa Barat ketika perjalanan kereta api tidak dapat ditempuh dalam waktu hanya satu hari sehingga baik perusahaan kereta api swasta maupun milik pemerintah membuka kantor-kantornya dan menempatkan para pegawainya di kota ini. Beberapa dari mereka yang bekerja di perusahaan kereta api ini lalu membentuk sebuah lembaga swasta bernama Archaeologische Vereeniging van Jogjakarta di tahun 1885 dengan Ir. Jan Willem Ijzerman sebagai ketuanya dan hingga tahun 1902 berperan dalam pelestarian Candi Borobudur dan candi-candi di wilayah Yogyakarta dan sekitarnya. Penemuan-penemuan di bidang purbakala tersebut dapat dikatakan sebagai salah satu faktor utama pendorong pertumbuhan pariwisata di Yogyakarta, disamping faktor-faktor lain seperti kekayaan seni dan budaya kraton serta kemudahan dalam bidang transportasi. Minat kunjungan wisata ke Yogyakarta yang makin tinggi pada awal abad ke-20 kemudian direspon oleh organisasi kepariwisataan nasional, Vereeniging Touristen Verkeer (VTV), dengan membuka kantor cabang Official Tourist Bureau di Malioboro No. 6. ${ }^{6}$ Sejumlah biro wisata atau perjalanan juga membuka kantor cabangnya di kawasan yang berada di pusat kota ini, diantaranya Eastern Travel Bureau di Malioboro No. 8B dan di Toegoeweg No. 6. Pada tahun 1937 didirikan sebuah organisasi swasta Jogja Vooruit yang berperan dalam mempromosikan

6) VTV dibentuk tahun 1908 di Batavia untuk mengelola dan mempromosikan pariwisata di Hindia Belanda. Wardiyanta, "Perkembangan Pariwisata di Yogyakarta pada Masa Kolonial Belanda 1908-1942”, Tesis, (Yogyakarta: Program Pasca Sarjana UGM, 2000), hlm. 104-105. Lebih lanjut mengenai VTV, lihat Achmad Sunjayadi, "Vereeniging Touristen Verkeer Batavia (1908-1942): Awal Turisme Modern di Hindia Belanda”, Tesis (Jakarta: Fakultas Ilmu Pengetahuan Budaya UI, 2007). 
pariwisata Yogyakarta. Selain itu, beberapa agen pelayaran dan penerbangan turut membuka kantornya di kawasan ini, seperti N.V. Java-China-Japan Lijn, KLM, dan KNILM. Malioboro pun kian ramai oleh para wisatawan, baik wisatawan domestik maupun mancanegara.

Meningkatnya jumlah orang-orang yang datang maupun menetap di Yogyakarta mendorong kebutuhan akan penginapan dan rumah-rumah, toko, tempat rekreasi dan hiburan, serta sarana kesehatan dan olahraga. Pada awal abad ke-20 Malioboro menjelma menjadi jalan pertokoan kolonial paling sibuk di Yogyakarta. Warung-warung yang sebelumnya telah ada berkembang menjadi toko-toko dengan bangunan permanen yang dibangun rapi di tepi jalan. Toko-toko baru lainnya pun tumbuh di kedua sisi jalan. Sama halnya dengan Groote Postweg (Jalan Raya Pos, sekarang Jalan Ahmad Yani) di Semarang, Bragaweg (Jalan Braga) di Bandung, Jalan Pasar Baru di Weltevreden, Jalan Tunjungan di Surabaya, Kayutangan (sekarang Jalan Basuki Rahmat) di Malang, atau jalan pertokoan kolonial lainnya di Jawa, di kanan-kiri jalan juga terdapat rumah-rumah, hotel, kantor, restoran, dan bioskop. Baik rumah, toko, kantor/biro, restoran, maupun hotel ini dimiliki oleh orang-orang Tionghoa, Eropa, Pribumi, Jepang, India, dan sebagainya dengan membeli tanah eigendom yang diiklankan di surat kabar atau dengan menyewa tanah di Malioboro yang merupakan Sultan Ground (SG). Selama periode kolonial, jalan yang mendapat julukan "De Broadway van Djokja" ini mencapai puncak keemasannya pada 1920-an hingga 1930-an sebelum akhirnya terkena imbas dari Depresi Ekonomi Global yang mengakibatkan harga-harga di Malioboro cenderung tidak stabil dan beberapa toko terpaksa harus gulung tikar. ${ }^{7}$

Berbeda dengan Braga di Kota Bandung yang terkesan sangat Eropa sehingga dijuluki sebagai "de meest Europeesche winkelstraat van Indie" atau "jalan pertokoan paling (bernuansa) Eropa di seluruh Hindia”, Malioboro justru terkesan lebih multikultural karena seperti halnya penduduk Kota Yogyakarta yang heterogen, orang-orang di Malioboro juga terdiri dari bermacam-macam etnis dan golongan. Meskipun demikian, pedagang Eropa dan Tionghoa lebih mendominasi daripada pedagang Jepang, India, dan Pribumi. Toko-toko Eropa banyak terdapat di ruas Malioboro dan ruas Toegoeweg sedangkan ruko-ruko Tionghoa banyak terdapat di ruas Patjinan. Selebihnya baik toko Jepang, India, maupun Pribumi tersebar di sepanjang ruas Toegoeweg hingga Patjinan diantara toko-toko Eropa dan Tionghoa.

Sebagai kawasan perbelanjaan, hampir semua item yang dibutuhkan masyarakat ada di Malioboro, mulai dari barang primer hingga tersier baik dari dalam maupun luar negeri. Ada toko mode dan pakaian serta salon tata rambut yang berkiblat pada tren Eropa, terutama Paris; barbershop; toko

7) Sekilas mengenai dampak malaise di Malioboro dan Kota Yogyakarta dapat dilihat di “Djokjasche causerie”, dalam De Indische courant, No. 283, 1 September 1931, hlm. 8 


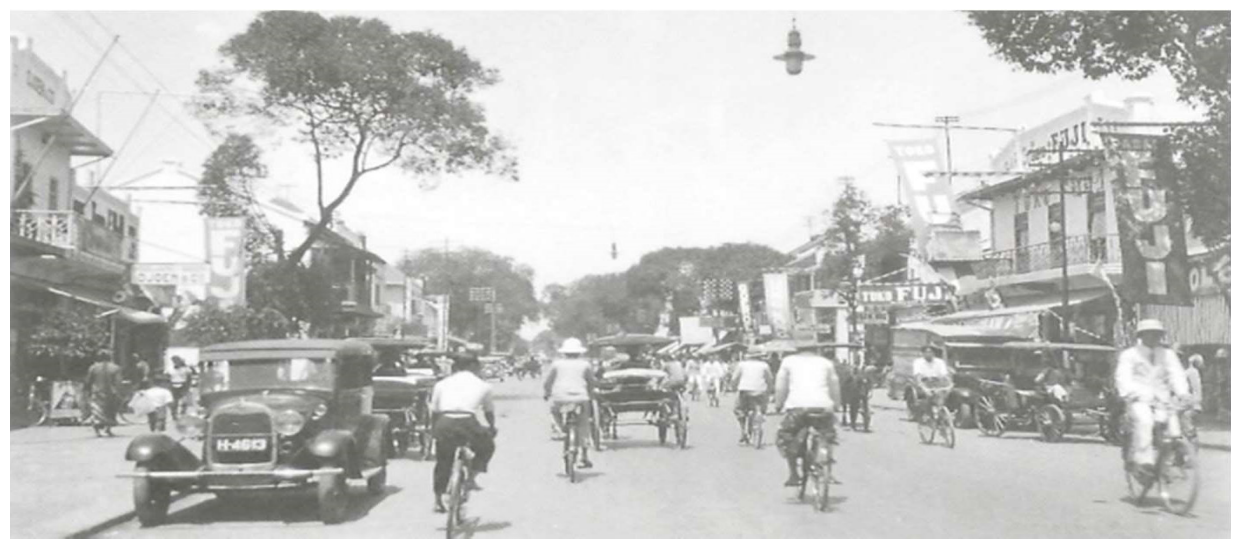

Figur 8. Ruas Patjinan dan ruas Malioboro dengan bangunan-bangunannya yang jauh lebih moderen dan kebaratan setelah awal 1920-an sebagaimana yang terlihat dalam foto sekitar tahun 1935 ini. Pada latar depan foto tampak toko "Fuji" di kedua sisi jalan dan di sisi kiri atau timur jalan terdapat toko roti "Djoen \& Co." milik orang Tionghoa. Toko Fuji yang didirikan oleh Osawa Kenji dan sejak tahun 1915 dikelola oleh Sawabe Masao ini merupakan toko Jepang terbesar di Malioboro. Foto: J. Anten. Sumber: Bruggen, van M.P., Wassing, R.S., dkk., Djokja en Solo Beeld van de Vorstensteden (Purmerend: Asia Maior, 1998), hlm. 133.

batik serta kerajinan dan seni dari berbagai daerah di Jawa dan Bali; toko roti; toko buku dan percetakan; toko rokok dan tembakau; toko bunga; studio foto; toko musik; toko sepeda, motor, dan mobil lengkap dengan bengkel dan aksesorisnya; berbagai apotek atau toko obat ala Eropa, Cina, dan Jawa; toko jam; toko optik; toko perhiasan; toko sepatu; toko radio; toko makanan dan minuman; toko mebel; toko besi yang banyak dimiliki oleh pengusaha Tionghoa; toko barang pecah belah; toko stempel; toko mesin jahit; toko es krim dan perusahaan es; toko kelontong dan toserba yang banyak dibuka oleh orang-orang Jepang; toko peralatan listrik; warung opium milik Tionghoa di ruas Patjinan dekat Ketandan ${ }^{8}$; toko kain 'bombay' yang dibuka oleh orangorang India; dan lain-lain. Toko biasanya dibuka pada pagi hingga siang hari kemudian dibuka kembali jelang sore hingga malam. Pada hari libur atau hari-hari tertentu kerap diadakan diskon yang menarik banyak pembeli.

Selain toko, ada pula yang menawarkan jasa keamanan malam, servis radio, broker untuk sekuritas dan produk, pembuat instrumen atau industri mekanik, biro mekanik untuk air ledeng dan penerangan listrik, berbagai perusahaan dagang, dokter gigi, pengacara, kantor asuransi, kantor akuntan dan administrasi, kantor dewan tanah, stasiun radio, perusahaan surat kabar, yayasan, dan sebagainya. Restoran dan snoephuis (snoep= manis/ kue, huis=rumah) tersebar di sepanjang Malioboro. Beberapa restoran di Malioboro ini tidak hanya menyediakan makanan dan minuman, tetapi juga menyediakan pub dan hiburan lainnya. Disamping itu, terdapat sejumlah bioskop di Malioboro yang sering memutar film-film impor dari luar negeri.

Hotel-hotel kelas satu di Yogyakarta semuanya berjajar di Malioboro:

8) Nama Ketandan (ke-tanda-an) adalah tempat bermukim tanda, yaitu lurah pasar yang bertugas menarik pajak di pasar (Jansz, 1906: 1033 dalam Raap, 2015: 96). 
Hotel Tugu, Hotel Mataram, Hotel Centrum, dan Grand Hotel de Djokja (sekarang Hotel Grand Inna Malioboro). Diantara keempat hotel milik Eropa tersebut, Grand Hotel de Djokja merupakan hotel terbaru (1911), sedangkan Hotel Tugu berdasarkan iklan-iklan di surat kabar merupakan hotel tertua yang setidaknya sudah ada pada tahun 1884 sebelum Stasiun Tugu selesai dibangun. Selain hotel-hotel kelas wahid ini, terdapat pula Hotel Trio di ruas Toegoeweg No. 8 milik seorang Tionghoa bernama Tjoa Boen Hian dan Hotel Hwa Kiauw di ruas Patjinan No. 502 milik sebuah perkumpulan Tionghoa Hwa Kiauw. Diantara hotel-hotel itu ada yang menawarkan fasilitas mandi air panas, kolam renang, penerjemah, pertunjukkan seni, serta kuliner ala Eropa, Jawa, dan Tionghoa.

Tabel 1 adalah list sejumlah toko, kantor, restoran, bioskop, dan hotel di Malioboro jelang akhir periode kolonial beserta alamatnya.

Tak hanya sebagai tempat untuk berbelanja, Malioboro juga menjadi tempat favorit untuk bersantai. Trotoarnya yang lebar dan teduh membuat siapapun merasa betah berjalan-jalan di kedua sisi jalannya sambil menikmati suasana Malioboro. Berbagai prosesi kerajaan, perayaan, pesta, festival, parade dan acara-acara lainnya pun diselenggarakan disini, misalnya prosesi penyambutan tamu kerajaan dari Pesanggrahan Ambarukmo atau Stasiun Tugu menuju Loji Kebon atau Kraton, arak-arakan pengantin dari Kraton ke Kompleks Kepatihan, arak-arakan pusaka Kanjeng Kyai Tunggul Wulung dalam rangka upacara tolak bala, perayaan dan parade Hari Ratu (Koninginnedag), festival lampu dalam Edison-Week, perayaan tahun baru Masehi dan tahun baru Cina, perayaan Natal, dan sebagainya yang dapat disaksikan oleh masyarakat. Pada malam hari, kawasan ini semakin ramai, terutama sejak hadirnya lampu penerangan jalan dari gas tahun 1889 yang beralih ke listrik pada 1917.

\section{Penutup}

Malioboro yang awalnya berfungsi sebagai rajamarga utuk seremonial kerajaan dan sebagai jalan hubung antara Kraton dan Tugu serta akses ke Kompleks Kepatihan dan Pasar Gedhe lambat laun berkembang menjadi jalan pertokoan kolonial paling modern dan paling ramai di Yogyakarta pada awal abad ke20 dengan puncaknya tahun 1920-30an. Hal tersebut setidaknya disebabkan oleh beberapa faktor: (1) lokasi Malioboro yang strategis; (2) pembangunan sarana transportasi; (3) perkembangan di bidang pariwisata; (4) kebijakan pemerintah yang memudahkan para investor atau pengusaha swasta untuk membuka usaha; dan (5) kemajuan di bidang teknologi, seperti penerangan, dll. Seperti jalan pertokoan kolonial lainnya di Jawa, di kanan-kiri Malioboro juga terdapat rumah-rumah, hotel, kantor, restoran, dan bioskop. Secara karakteristik, bangunan di sisi barat ruas Toegoeweg-Malioboro didominasi oleh pertokoan; sisi timur Toegoeweg-Malioboro didominasi oleh perhotelan 
dan perkantoran; kedua sisi ruas Patjinan didominasi oleh pertokoan; dan kedua sisi Residentielaan-Kadasterstraat didominasi oleh perkantoran dan fasilitas administrasi-politik kolonial.

Tabel 1. "Daftar Beberapa Nama dan Alamat Pertokoan, Perkantoran, Perhotelan, Restoran, dan Bioskop di Malioboro Tahun 1937 hingga 1940.* Beberapa toko menjadi pemasok rumah tangga kerajaan (hofleverancier), seperti The Tailor Company dan Fonteyn \& Co.

\begin{tabular}{|c|c|}
\hline Nama Toko, Restoran, Bioskop, Kantor & Alamat \\
\hline Toko Kerajinan ‘Kunstarbeid' & Toegoeweg No. 1 \\
\hline $\begin{array}{l}\text { Biro Perjalanan 'Eastern Travel Bureau' } \\
\text { Makelar 'Droste \& Wejnschenk' } \\
\text { N.V. Java-China-Japan Lijn } \\
\text { KLM } \\
\text { KNILM }\end{array}$ & Toegoeweg No. 6 \\
\hline Hotel Trio & Toegoeweg No. 8 \\
\hline Toko Mode 'The Tailor Company' & Toegoeweg No. 10 \\
\hline Dokter Gigi Tjoa Som Gwan & Toegoeweg No. 12 \\
\hline $\begin{array}{l}\text { Perusahaan Produksi 'Tan Oen Hwie' } \\
\text { Advokat Mr. R. Soejadi }\end{array}$ & Toegoeweg No. 18 \\
\hline Autohandel Fuchs en Rens & Toegoeweg No. 20 \\
\hline Restaurant en Ice Cream Palace Toko Oen & Toegoeweg No. 22 \\
\hline Biro Teknik G.C.E. de Man & Toegoeweg No. 23 \\
\hline $\begin{array}{l}\text { Toko Roti ‘Oen’ } \\
\text { Toko Roti ‘Bruins en Tyssen’ }\end{array}$ & Toegoeweg No. 24 \\
\hline $\begin{array}{l}\text { Kantor Algemeen Bioscoop Bedrijf } \\
\text { Rex Theater }\end{array}$ & Toegoeweg No. 26 \\
\hline H.J. Sneep & Toegoeweg No. 29 \\
\hline Mode Atelier Mevr. M.A. Keasberry & Toegoeweg No. 30 \\
\hline Yap \& Mode Atelier & Toegoeweg No. 32 \\
\hline Boekhandelaren E.M.J. Ribbens & Toegoeweg No. 34 \\
\hline Perusahaan Piano ‘Gebr. Jung' & Toegoeweg No. 36 \\
\hline $\begin{array}{l}\text { Toko Pakaian Anak dan Mode 'N.V. Midden Java' } \\
\text { Perusahaan Rokok dan Tembakau 'F.C. Misset \&' Co }\end{array}$ & Toegoeweg No. 38 \\
\hline V.P.L. (Vereeniging Personeel Landskantooren) & Toegoeweg No. 40 \\
\hline Stichting Djokjasche Werkcentrale & Toegoeweg No. 42 \\
\hline $\begin{array}{l}\text { Alderden's Bloemenmagazijn } \\
\text { Muziekhandel "Lyra" J.H. Goldberg }\end{array}$ & Toegoeweg No. 44 \\
\hline N.V. Carl Schlieper Handel Mij. & Toegoeweg No. 46 \\
\hline $\begin{array}{l}\text { Dameskapsalon Maison Jenny } \\
\text { J.A. Dezentje Hamming (Sun Life of Canada) }\end{array}$ & Toegoeweg No. 50 \\
\hline Mille Fleurs & Toegoeweg No. 52 \\
\hline Rumah E.J. van der Beek (direktur Zelf Bestuurswerken) & Toegoeweg No. 54 \\
\hline
\end{tabular}

*) Penomoran bangunan di sepanjang Malioboro didasarkan pada peraturan pemerintah yang dimuat dalam Javaasche Courant tanggal 25 Oktober 1901 No. 85. Dalam peraturan tersebut, tiap bangunan wajib dinomori secara urut dari selatan ke utara dengan angka genap untuk bangunan di sisi timur dan angka ganjil untuk bangunan di sisi barat, sedangkan bangunan-bangunan baru yang didirikan ditengah-tengah bangunan lama harus dinomori seperti nomor bangunan yang terdekat dengan menambah huruf 'a', 'b', 'c', dan seterusnya di belakang angka. Selain itu, di bagian depan fasad bangunan juga harus diberi papan permanen yang berisi keterangan angka dan nama wilayah atau nama pemilik bangunan (Rijksblad van Sultanaat Djogjakarta Tahun 1922 No. 2 dan No. 3). 
Toko Musik W. Naessens \& Co

Surat Kabar Harian 'Mataram'

Advokat Mr. Liem Soen Ging

Toko Optik 'J.H. Goldberg'

Klaarwater

N.V. Andriesse

Toko Mode 'Medan'

Particuliere Nachtveiligheidsdienst

Perusahaan Mobil 'N.V. Velodrome'

Lab. Voor de Lederbewerking der Afd. Nijverheid v/h Dept. Econ. Zaken Instrumentmakkerij (Fijn. Mechanische Industrie C.J. Stephanus)

Toko S.H.B.

Mej. E. Harting

Dameskapsalon Maison Paula

Toko Makanan dan Minuman 'Fen'

Duco \& Kappenmakerij Victory

Aardappelhandel S. Makino

Toko Roti 'Poa Ping Hie'

Parla Gramofoon

Che Nam Restaurant

Toko mebeul dan radio "Liong Wing"

Fa. S.E. Gobee \& Co

Kantor pusat Centrale Pensioenbank (C.P.B.)

Salon de Coiffeur pour Dames

Eastern Travel Bureau

N.V. van Wingen

Loge Mataram

F.W. Roijen

Hotel Mataram

Autohandel en Rep. Atelier A. van Deutekom

Vadera (Van Deutekom Radio)

Centrale Administratie der Werkloosheidsbestrijding

Zender V.I.R.O.M.

Grand Hotel de Djokja

Lim Hsing Yen

Meubel Industrie "Lie Jan"

BATA

N.V. Chemicalienhandel Rathkamp \& Co.

Toyo \& Co. (Toko Japan Schikanari)

Coiffeurszaak "Maison Egberts"

Kyodo Optical Co.

Toko Perhiasan 'Fonteys \& Co'

Alliance Boekhandel

D.J. Egberts

Toko Payung Tjiamis

Mej. Lauw Foe Joeng

Fotograaf en Fotohandel J.H. Zindler

Coiffeur pour Dames et Messieurs "Maison Renders"
Toegoeweg No. 56

Toegoeweg No. 58

Toegoeweg No. 60

Toegoeweg No. 62 \& 63

Toegoeweg No. 66

Toegoeweg No. 77

Toegoeweg No. 79

Toegoeweg No. 93

Toegoeweg No. 99

Toegoeweg No. 101

Toegoeweg No. 105

Toegoeweg No. 107

Toegoeweg No. 109

Toegoeweg No. 111

Toegoeweg No. 125

Toegoeweg No. 129

Toegoeweg No. 133

Toegoeweg No. 407

Malioboro No. 2

Malioboro No. 2A

Malioboro No. 6

Malioboro No. 8

Malioboro No. 8B

Malioboro No. 12

Malioboro No. 16

Malioboro No. 18

Malioboro No. 20

Malioboro No. 22

Malioboro No. 24

Malioboro No. 27

Malioboro No. 29

Malioboro No. 39A

Malioboro No. 41

Malioboro No. 43

Malioboro No. 51

Malioboro No. 53

Malioboro No. 55

Malioboro No. 57

Malioboro No. 61

Malioboro No. 63

Malioboro No. 79

Malioboro No. 82 
Toko Jam, Optik, dan Perhiasan 'A.E. Mayer'

Malioboro No. 87

Juliana Apotheek

Malioboro No. 89

Apotek J. Van Gorkom \& Co

Tjan Bing Hing

Malioboro No. 91

Toko Terang

Malioboro No. 93

Toko Pakaian Pria dan Mode 'W. Savelkoul'

Malioboro No. 95

Indisch Verzendhuis N.V. Gebr. Cramer

Malioboro No. 97

Joop v.h. Aneta

Motorhandel en reparatie atelier M. Hoeri

Malioboro No. 99

Malioboro No. 89

Toko Roti 'Weltevreden'

Malioboro No. 139

Toko Tjampoersari

Toko Permen dan Manisan 'Maison Voorhouders'

Malioboro No. 141

Boekhandel Kolff Buning

Malioboro

Malioboro

Dialdas, i.k.s. Toko Bombay

Malioboro

Toko Mori

Patjinan No. 7

Toko Makanan dan Minuman 'Paris'

Patjinan No. 11A

Toko Onderdil Mobil 'Baroe'

Patjinan No. 17

Toko Obral

Patjinan No. 21

Djoen \& Co

Patjinan No. 22

Toko Besi Tio Sing

Toko Ing Lan (barang pecah belah)

Patjinan No. 29

Toko Besi 'Lam Djiang \& Co'

Patjinan No. 30

N.V. Handel Mij. Hoo Hap

Patjinan No. 32

Eng Gwan Hien

Toko Makanan dan Minuman 'Gondok'

Patjinan No. 36

Tric-Trac Ice Cream Palace (cabang Toko Oen)

Patjinan No. 36A

Toko Mori

Tie Poo Kia

Toko Besi 'Tik Gwan \& Co'

Toko Gie Thaij

Perusahaan Batik plus Makanan dan Minuman 'Njonja The Tjien Sing'

Toko London

Restaurant Malang

Toko Japan "Hama"

Toko Roti 'Djoen \& Co'

Perusaan Klise dan Stempel 'Lie Kam Hong'

Toko Makanan dan Minuman 'Mij. N.V.H. Tan Siem Pie'

Toko Listrik dan Radio 'Kashima'

Toko Tjoen Tay

Toko Menang

Toserba Jepang 'N.V. Tjijoda'

N.V. Kian Gwan

Patjinan No. 36B

Patjinan No. 38

Patjinan No. 39

Patjinan No. 40

Patjinan No. 43

Patjinan No. 45

Patjinan No. 46

Patjinan No. 47

Patjinan No. 50

Patjinan No. 51C

Patjinan No. 50

Patjinan No. 54

Patjinan No. 57

Toko Ramai

Toko Makanan dan Minuman 'Kion Hwa'

Toko Lie Ing Tjioe

Toko besi Woo Hing

Toko Siam

Toko P.A.L.O.E. 


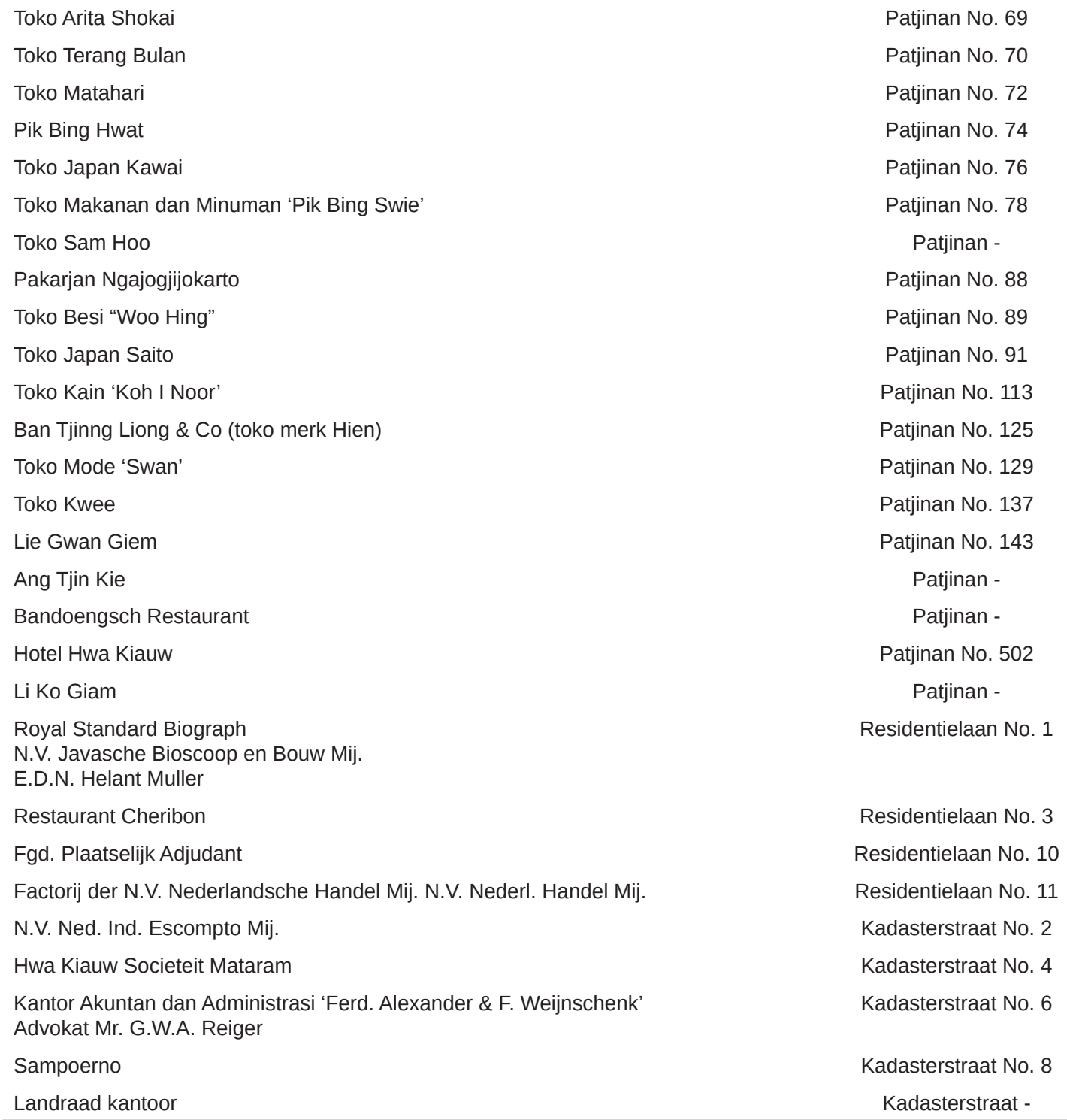

Sumber: Diolah dari Telefoongids voor Java, Madoera en Bali No. 47, 49, dan 50.

\section{Daftar Pustaka}

\section{Arsip}

Bijblad op het Staatsblad van Nederlandsch-Indie, 1939.

Gegevens over Djokjakarta, 1925.

Gegevens over Djokjakarta, 1926 A.

Gegevens over Djokjakarta, 1925 B.

Kleian's Adresboek van Geheel Nederlandsch-Indie, 1923.

Kleian's Adresboek van Geheel Nederlandsch-Indie, 1930.

Kleian's Adresboek van Geheel Nederlandsch-Indie, 1934.

Kleian's Adresboek van Geheel Nederlandsch-Indie, 1941.

Rijksblad van Sultanaat Djogjakarta, 1916-1941.

Telefoongids voor Java, Madoera en Bali, No. 47, Januari 1938.

Telefoongids voor Java, Madoera en Bali, No. 49, Mei 1939.

Telefoongids voor Java, Madoera en Bali, No. 50, Januari 1940. 


\section{Majalah \& Surat Kabar}

Bataviaasch Nieuwsblad, No. 69, 22 Februari 1912.

Bataviaasch Nieuwsblad, No. 7, 09 Desember 1912.

Bataviaasch Nieuwsblad, No. 121, 27 April 1914.

Bataviaasch Nieuwsblad, No. 123, 25 April 1916.

Bataviaasch Nieuwsblad, No. 142, 17 Mei 1916.

Bataviaasch Nieuwsblad, No. 610, 30 November 1918.

Bataviaasch Nieuwsblad, No. 267, 12 Mei 1920.

Bataviaasch Nieuwsblad, No. 292, 29 Mei 1920.

Bataviaasch Nieuwsblad, No. 440, 08 September 1920.

Bataviaasch Nieuwsblad, No. 47, 26 Januari 1924.

Bataviaasch Nieuwsblad, No. 132, 10 Mei 1924.

Bataviaasch Nieuwsblad, No. 53, 05 Februari 1930.

Bataviaasch Nieuwsblad, No. 139, 21 Mei 1930.

Bataviaasch Nieuwsblad, No. 87, 27 Desember 1930.

Bataviaasch Nieuwsblad, No. 161, 05 Juni 1940.

De Locomotief, No. 260, 30 Oktober 1884.

De Indische Courant, No. 149, 21 Maret 1922.

De Indische Courant, No. 174, 21 April 1922.

De Indische Courant, No. 284, 28 Agustus 1923.

De Indische Courant, No. 70, 06 Desember 1923.

De Indische Courant, No. 109, 24 Januari 1924,

De Indische Courant, No. 200, 15 Mei 1924.

De Indische Courant, No. 219, 07 Juni 1924.

De Indische Courant, No. 67, 2 Desember 1925.

De Indische Courant, No. 93, 15 Januari 1926.

De Indische Courant, No. 109, 23 Januari 1926.

De Indische Courant, No. 137, 26 Februari 1926.

De Indische Courant, No. 155, 20 Maret 1926.

De Indische Courant, No. 163, 30 Maret 1926.

De Indische Courant, No. 199, 15 Mei 1926.

De Indische Courant, No. 235, 29 Juni 1926.

De Indische Courant, No. 184, 27 April 1926.

De Indische Courant, No. 249, 15 Juli 1926.

De Indische Courant, No. 278, 20 Agustus 1926

De Indische Courant, No. 283, 26 Agustus 1926.

De Indische Courant, No. 30, 30 September 1926.

De Indische Courant, No. 278, 17 Agustus 1928.

De Indische Courant, No. 51, 13 November 1928.

De Indische Courant, No. 293, 7 September 1929.

De Indische Courant, No. 34, 24 Oktober 1929.

De Indische Courant, No. 175, 12 April 1930.

De Indische Courant, No. 213, 2 Juni 1930.

De Indische Courant, No. 235, 28 Juni 1930.

De Indische Courant, No. 255, 22 Juli 1930.

De Indische Courant, No. 37, 27 Oktober 1930.

De Indische Courant, No. 209, 30 Mei 1931.

De Indische Courant, No. 242, 08 Juli 1931. 
De Indische Courant, No. 257, 25 Juli 1931.

De Indische Courant, No. 251, 18 Juli 1931.

De Indische Courant, No. 24, 12 Oktober 1931.

De Indische Courant, No. 66, 30 November 1931.

De Indische Courant, No. 110, 25 Januari 1932.

De Indische Courant, No. 5, 20 September 1932.

De Indische Courant, No. 170, 9 April 1934.

De Indische Courant, No. 128, 15 Februari 1936.

De Indische Courant, No. 202, 15 Mei 1936.

De Indische Courant, No. 214, 30 Mei 1936.

De Indische Courant, No. 87, 27 Desember 1939.

De Preanger-Bode, No. 309, 11 November 1911.

De Preanger-Bode, No. 360, 27 Desember 1916.

De Preanger-Bode, No. 333, 02 Desember 1918.

Het Nieuws van den Dag voor Nederlandsch-Indie, No. 155, 06 Juli 1912.

Het Nieuws van den Dag voor Nederlandsch-Indie, No. 219, 21 September 1912.

Het Nieuws van den Dag voor Nederlandsch-Indie, No. 1, 02 Januari 1915.

Het Nieuws van den dag voor Nederlandsch-Indie, No. 251, 26 Oktober 1916.

Het Nieuws van den dag voor Nederlandsch-Indie, No. 218, 14 September 1918.

Het Nieuws van den Dag voor Nederlandsch-Indie, No. 292, 14 Desember 1920.

Het Nieuws van den dag voor Nederlandsch-Indie, No. 85, 12 April 1923.

Het Nieuws van den Dag voor Nederlandsch-Indie, No. 110, 13 Mei 1924.

Het Nieuws van den Dag voor Nederlandsch-Indie, No. 202, 27 Agustus 1926.

Het Nieuws van den Dag voor Nederlandsch-Indie, No. 238, 15 Oktober 1928.

Het Nieuws van den Dag voor Nederlandsch-Indie, No. 292, 17-Desember 1928.

Het Nieuws van den Dag voor Nederlandsch-Indie, No. 212, 17 September 1929.

Het Nieuws van den Dag voor Nederlandsch-Indie, No. 32, 08 Februari 1930.

Het Nieuws van den Dag voor Nederlandsch-Indie, No. 145, 27 Juni 1930.

Het Nieuws van den Dag voor Nederlandsch-Indie, No. 21, 26 Januari 1932.

Kabare, Edisi 156 Tahun XIII, Juni 2015.

Limburgsch Dagblad, No. 175, 26 Juli 1928.

Mooi Jogjakarta, Yogyakarta: Drukkerij en Boekhandel Kolff Buning, t.t.

Nieuwe Courant, No. 396, 03 Mei 1949.

Nieuwe Courant, No. 400, 07 Mei 1949.

Soerabaijasch Handelsblad, No. 5, 07 Januari 1929.

Soerabaijasch Handelsblad, No. 45, 25 Februari 1929.

Soerabaijasch Handelsblad, No. 104, 10 Mei 1929.

Soerabaijasch Handelsblad, No. 140, 24 Juni 1929.

Soerabaijasch Handelsblad, No. 188, 20 Agustus 1929.

Soerabaijasch handelsblad, No. 204, 09 September 1929.

Soerabaijasch Handelsblad, No. 209, 16 Oktober 1929.

Soerabaijasch Handelsblad, No. 220, 29 Oktober 1929.

Soerabaijasch Handelsblad, No. 226, 05 November 1929.

Soerabaijasch Handelsblad, No. 268, 27 Desember 1929.

Soerabaijasch Handelsblad, No. 237, 18 Oktober 1930.

Soerabaijasch Handelsblad, No. 42, 21 Februari 1931.

Soerabaijasch Handelsblad, No. 61, 16 Maret 1931.

Soerabaijasch Handelsblad, No. 135, 15 Juni 1935. 
Soerabaijasch Handelsblad, No. 19, 23 Januari 1936.

Soerabaijasch handelsblad, No. 37, 12 Februari 1936.

Soerabaijasch Handelsblad, No. 83, 12 April 1937.

Soerabaijasch handelsblad, No. 21, 25 September 1937.

\section{Artikel Jurnal}

Carey, Peter (1984). 'Jalan Maliabara ('Garland Bearing Street'): The Etymology and Historical Origins of a much Misunderstood Yogyakarta Street Name', Jurnal Archipel, Vol. 27: 51-62.

Didi Kwartanada (2002). 'Competition, Patriotism and Collaboration: The Chinese Businessman of Yogyakarta between the 1930s and 1945', Journal of Southeast Asian Studies 33, 2: 257-277.

Noorduyn, J. (1986). “The Etymology of the Name of Yogyakarta', Archipel, Vol. 31: 87-96.

Tashadi (2005). 'Senisana dalam Perjalanan Sejarah: Kasus pada Era Republik Indonesia 1945-1992', Patra-Widya, Vol. 6 No. I: 45-73.

Buku

Abdurrachman Surjomihardjo (2008). Kota Yogyakarta Tempo Doeloe: Sejarah Sosial 1880-1930. Depok: Komunitas Bambu.

Arwan Tuti Artha (2000). Yogyakarta Tempo Doeloe: Sepanjang Catatan Pariwisata. Yogyakarta: Bigraf Publishing.

Bruggen, M.P.V. and Wassing (1998). Djokja en Solo: Beeld van de Vorstensteden. Purmerend: Asia Maior.

Carey, Peter; Noorduyn, Jacobus (Koos); dan Ricklefs, M.C. (2015). Asal Usul Nama Yogyakarta dan Malioboro. Depok: Komunitas Bambu.

Dharma Gupta, dkk. (eds.) (2007). Toponim Kota Yogyakarta. Yogyakarta: Dinas Pariwisata, Seni, dan Budaya Kota Yogyakarta.

Djoko Soekiman (2014). Kebudayaan Indis: Dari Zaman Kompeni sampai Revolusi. Jakarta: Komunitas Bambu.

Dwi Ratna Nurhajarini, dkk. (2012). Yogyakarta: Dari Hutan Beringan ke Ibukota Daerah Istimewa. Yogyakarta: Kementerian Pendidikan dan Kebudayaan Balai Pelestarian Sejarah dan Nilai Tradisional Yogyakarta.

Groneman, J. (1900). Reisgids voor Jogjakarta en Omstreken. Yogyakarta: W.A. van der Hucht \& Co.

(1900). Reisgids voor Jogjakarta en Omstreken. Semarang: Semarang-Drukkerij en Boekhandel H. A. Benjamins.

Handinoto (2010). Arsitektur dan Kota-Kota di Jawa Pada Masa Kolonial. Yogyakarta: Graha Ilmu.

(2015). Perkembangan Kota di Jawa Abad XVIII sampai Pertengahan Abad XX: Dipandang dari Sudut Bentuk dan Struktur Kotanya. Yogyakarta: Komunitas Bambu.

Inajati Adristijanti Romli dan Anggraeni (eds.) (2003). Mosaik Pusaka Budaya Yogyakarta. Yogyakarta: Balai Pelestarian Cagar Budaya Yogyakarta.

Ir. Yuwono Sri Suwito, M.M., dkk. (2004). Hari Jadi Kota Yogyakarta. Yogyakarta: Dinas Pariwisata, Seni, dan Budaya.

Knaap, Gerrit (1999). Cephas: Yogyakarta Photography in the Service of the Sultan. Leiden: KITLV Press.

Krafft, A.J.C. (1935). Prachtige Tochten van uit Magelang. Magelang: Mareesch. 
KUNCI (2011). Des Indes Orientales: Sejarah Komunitas India di Yogyakarta, Yogyakarta: KUNCI.

Kuntowijoyo (2003). Metodologi Sejarah. Yogyakarta: Tiara Wacana.

Leushuis, Emile (2014). Panduan Jelajah Kota-Kota Pusaka di Indonesia. Yogyakarta: Ombak.

M. Rosyid Ridlo (2013). The Guide Book of Benteng Vredeburg Museum. Yogyakarta: Museum Benteng Vredeburg.

Meta Sekar Puji Astuti (2008). Apakah Mereka Mata-Mata? Orang-Orang Jepang di Indonesia (1868-1942). Yogyakarta: Ombak.

Mrazek, Rudolf (2006). Engineers of Happy Land: Perkembangan Teknologi dan Nasionalisme di Sebuah Koloni. Yogyakarta: Yayasan Pustaka Obor Indonesia.

Nordholt, Henk Schulte, Bambang Purwanto, dan Ratna Saptari (eds.) (2008). Perspektif Baru Penulisan Sejarah Indonesia. Jakarta: Yayasan Pustaka Obor bekerjasama dengan KITLV-Jakarta.

Panitya Peringatan Kota Jogjakarta 200 Tahun (1956). Kota Jogjakarta 200 Tahun. Yogyakarta: Panitia Peringatan.

Raap, Olivier Johannes (2015). Kota di Djawa Tempo Doeloe. Jakarta: Kepustakaan Populer Gramedia.

Ridwan Hutagalung dan Taufanny Nugraha (2008). Braga: Jantung Parijs van Java. Depok: KA Bandung.

Ryadi Goenawan (1984/1985). Sejarah Sosial Daerah: Daerah Istimewa Yogyakarta, Mobilitas Sosial D. I. Yogyakarta Periode Awal Abad XX-an. Jakarta: Departemen Pendidikan dan Kebudayaan Direktorat Sejarah dan Nilai Tradisionl Proyek Inventarisasi dan Dokumentasi Sejarah Nasional.

Soedomo Bandjaransari dan Tjeng Tik Kie (1956). Buku Kenang-Kenangan: Peringatan 200 Tahun Kota Jogjakarta, 1756-1956. Yogyakarta: t.p.

Stevens, Dr. Th. (2004). Tarekat Mason Bebas dan Masyarakat di Hindia Belanda dan Indonesia 17641962. Jakarta: Pustaka sinar Harapan.

Sudarsono Katam (2017). Nostalgia Bragaweg Tempo Doeloe 1930-1950. Bandung: PT Dunia Pustaka Jaya.

Soekanto (1952). Sekitar Jogjakarta 1755-1825. Jakarta: Mahabarata.

Sunyoto Usman, (ed.) (2006). Malioboro. Yogyakarta: PT. Mitra Tata Persada.

Tio Tek Hong (2006). Keadaan Jakarta Tempo Doeloe: Sebuah Kenangan 1882-1959. Jakarta: Masup Jakarta.

Umar Priyono, dkk. (2015). Buku Profil Yogyakarta “City of Philosophy”. Yogyakarta: Dinas Kebudayaan Daerah Istimewa Yogyakarta.

V. Wiratna Sujarweni (2012). Yogyakarta: Episode Jejak-Jejak Mataram Islam. Yogyakarta: Global Media Informasi.

Van der Veur, Paul W. (2012). Freemasonry di Indonesia:Jaringan Zionis Tertua yang Mengendalikan Nusantara. Jakarta: Ufuk Press.

Van Kol, H. H., “De Residentie Djokjakarta”, Indishe Gids, 26: 1465-1482, 1904.

\section{Skripsi, Tesis, Disertasi}

Achmad Sunjayadi (2007). Vereeniging Touristen Verkeer Batavia (1908-1942): Awal Turisme Modern di Hindia Belanda (Tesis, Universitas Indonesia, Jakarta).

Bambang Hari Wibisono (2001). The Transformation of Jalan Malioboro, Yogyakarta: The Morphology and Dynamics of A Javanese Street (Disertasi, University of Melbourne, Melbourne). 
Siti Mahmudah Nur Fauziah (2018). Malioboro Tempo Doeloe: Sejarah Kehidupan Sehari-Hari 1890-1950 (Skripsi, Universitas Gadjah Mada, Yogyakarta).

Wardiyanta (2000). Perkembangan Pariwisata di Yogyakarta pada Masa Kolonial Belanda 1908-1942 (Tesis, Universitas Gadjah Mada, Yogyakarta).

\section{Website}

www.delpher.nl

www.europeana.nl

www.kebudayaan.kemdikbud.go.id

www.kitlv.nl

www.tropenmuseum.nl

\section{Wawancara}

Wawancara dengan K.R.T. Jatiningrat, 10 Mei 2016 